\title{
ANALISIS PENGARUH LINGKUNGAN KERJA TERHADAP KINERJA KARYAWAN PADA PT TOLEDO TUKTUK SAMOSIR
}

\author{
Oleh \\ Efendi $^{1)}$, Marisi Butarbutar ${ }^{2)}$ \& Mangara Nababan ${ }^{3)}$ \\ 1,2,3 STIE Sultan Agung Pematangsiantar \\ Email: ${ }^{1}$ efendi.wu@ gmail.com, marisibutarbutar84@gmail.com \& \\ 3 mangaranababan0802@ gmail.com
}

\begin{abstract}
This research was conducted to see the job description and employee performance, and the influence of the work environment on employee performance at pt toledo tuktuk samosir. Methods of analysis with mixed methods (qualitative and quantitative). The results showed: good work environment and performance, and there is a positive and significant influence between the work environment on employee performance at pt toledo tuktuk samosir.
\end{abstract}

Keywords: Work Environment \& Performance

\section{PENDAHULUAN}

Danau Toba adalah salah satu destinasi wisata prioritas nasional, dengan dibentuknya Badan Otorita Pengelola Kawasan Pariwisata Danau Toba (Indonesia, 2016). Hal ini membuka peluang usaha yang sangat besar khususnya bidang jasa akomodasi salah satunya perhotelan. Pelayanan hotel yang secara langsung berinteraksi dengan tamu adalah karyawan hotel. Potensi yang dimiliki karyawan hotel perlu diberdayakan semaksimal mungkin, salah satunya dengan memberikan kompensasi bagi karyawan hotel. Kompensasi yang dimaksud tidak semata-mata hanya berupa uang saja, namun salah satu yang dapat dipertimbangkan pengelola atau pemilik hotel adaalah dengan memberikan kenyamanan bekerja bagi karyawan melalui lingkungan kerja yang mendukung kinerja karyawan. PT Toledo Tuktuk Samosir adalah perusahaan yang bergerak di bidang pelayanan, jasa perhotelan, yang berlokasi di Jl. Lingkar TukTuk siadong, Samosir - Sumatra Utara. Perusahaan ini memiliki kegiatan usaha yaitu menyediakan kamar bagi para wisatawan domestik ataupun mancanegara.

Kinerja karyawan yang optimal memegang peranan penting dalam pencapaian tujuan hotel (Lakoy, 2015). Kinerja yang optimal akan berpengaruh pada keberhasilan perusahaan. Kinerja karyawan dapat diukur melalui dimensi kuantitas, kualitas, ketepatan waktu, kehadiran, dan kemampuan bekerja sama. Berdasarkan hasil wawancara dengan manajer perusahaan, diperoleh data kinerja karyawan yang masih belum optimal, dengan kategori kinerja karyawan yang cukup baik sebesar 34\%. Hal ini terlihat pada dimensi kuantitas, dimana masih terdapat karyawan kurang serius dalam menyelesaikan pekerjaannya. Dalam dimensi kualitas, dimana kurangnya ketelitian dan kerapian karyawan pada saat bekerja sehingga mendapat keluhan dan kritik dari pelanggan.

Dalam dimensi ketepatan waktu, masih terdapat karyawan bermain handphone pada saat sedang bekerja sehingga waktu yang diberikan untuk suatu pekerjaan tidak terlaksana dengan baik. Dalam dimensi kehadiran, dimana masih terdapat karyawan menambah jadwal liburnya dari yang di tentukan oleh perusahaan. Selanjutnya untuk dimensi kemampuan bekerja sama masih kurang baik, hal ini di karenakan adanya karyawan yang tidak ingin membantu tim kerjanya ketika dalam kesulitan mengerjakan pekerjaan.

Salah satu faktor yang diindikasikan dapat mempengaruhi kinerja karyawan adalah lingkungan kerja. Sesuai pendapat (Winarti et 
al., 2016) mengatakan bahwa terdapat pengaruh yang positif dari lingkungan kerja dan kepuasan kerja terhadap kinerja karyawan. Dimensi lingkungan kerja pada PT Toledo Tuktuk Samosir, lingkungan kerja dari segi fisik dan lingkungan kerja segi non fisik. Fenomena lingkungan kerja pada PT Toledo Tuktuk Samosir terdapat dimensi lingkugan fisik yang meliputi pusat kerja, kursi, dan meja, namun belum optimal dalam meningkatkan kinerja karyawan, disebabkan rendahnya tingkat penataan ruangan belum optimal. Sedangkan lingkungan non fisik meliputi hubungan antar karyawan dan atasan juga belum optimal, hal ini terjadi disebabkan kurang efektifnya komunikasi antara karyawan dengan atasan sehingga karyawan kurang termotivasi.

\section{LANDASAN TEORI}

\section{Lingkungan Kerja}

Lingkungan kerja termasuk faktor penting yang sangat memiliki peranan terhadap output karyawan. Lingkungan kerja yang kondusif akan berdampak baik dalam mencapai output karyawan yang optimal. (Sedarmayanti, 2001), lingkungan kerja adakah seluruh peralatan kerja dan bahan yang dipakai, sekitar lingkungan dimana individu bekerja, cara kerja, manajemen kerja secara individu atau sebagai kelompok.

Menurut (Sedarmayanti, 2001), secara garis besar menyatakan bahwa lingkungan kerja terbagi menjadi dua yaitu: Lingkungan Kerja Fisik dan Lingkungan Kerja Non Fisik. Lingkungan kerja fisik menyangkut dengan pengaturan ruang kerja dan kebersihan dan kerapian, sedangan lingkungan kerja non fisik berhubungan dengan lingkungan sosial, status, hubungan kerja dan alur informasi.

Menurut (Sedarmayanti, 2001), terdapat berbagai faktor berpengaruh pada lingkungan kerja, yakni: pencahayaan, suhu ruangan, kelembapan, pertukaran udara, keributan, aroma ruangan, pewarnaan ruangan, dekorasi, alunan lagu, dan keamanan. Ada banyak hal yang dapat mempengaruhi aktivitas pegawai dalam melaksanakan pekerjaannya. Maka penting bagi suatu organisasi untuk memperhatikan lingkungan kerja yang ada demi meningkatkan kinerja para pegawai. Rasa nyaman di lingkungan kerja merupakan faktor krusial yang menjadi perhatian organisasi dalam upaya mencapai tujuannya.

\section{Kinerja Karyawan}

Kinerja karyawan adalah kemampuan individu atau pun karyawan dalam menyelesaikan kerja yang telah dibebankan. Jika hasil kerja yang telah dilaksanakan karyawan baik atau tidaknya akan bepengaruh terhadap tujuan organisasi. (Mathis and Jackson, 2006), kinerja adalah pencapaian output kerja individu akan tugas yang diterimanya atas atas semua potensi yang dimpilikinya serta waktu melaksanakannya.

Dalam pengukuran kinerja dibutuhkan dimensi yang dapat digunakan dalam pengukur kinerja tersebut. Menurut (Mathis and Jackson, 2006), menyatakan ada 5 dimensi yang dapat dipergunakan untuk megukur kinerja yaitu: 1) Kuantitas dari hasil kerja individu, 2) Kualitas dari hasil kerja, 3) Ketepatan waktu mengerjakan, 4) Kehadiran melakukan pekerjaan dengan disiplin, 5) Kemampuan kerja sama sebagai tim dalam bekerja. Dengan dimensi ini maka kinerja karyawan diharapkan dapat diukur dengan lebih baik.

\section{Pengaruh Lingkungan Kerja terhadap Kinerja Karyawan}

Kontribusi lingkungan kerja terhadap naik turunnya kinerja karyawan, dan hal ini sudah dibuktikan secara teoritis maupun melalui penelitian. Penelitian (Winarti et al., 2016), menemukan lingkungan kerja pegawai akan berpengaruh positif terhadap kinerja pegawai. Juga penelitian (Al-Omari and Okasheh, 2017) bahwa lingkungan kerja berpengaruh terhadap kinerja. Berdasarkan pendapat peneliti terdahulu diatas, maka kesimpulan yang dapat diambil adalah lingkungan kerja yang baik sangat memberikan kontribusi pada kinerja karyawan.

\section{Hipotesis}

Hipotesis dari penelitian ini adalah terdapat pengaruh yang positif dan signifikan 
antara lingkungan kerja terhadap kinerja karyawan.

\section{METODE PENELITIAN}

Penelitian ini dilakukan dengan studi kepustakaan dan penelitian lapangan. Objek penelitian adalah karyawan PT Toledo Tuktuk Samosir yang beralamat di Jl. Lingkar Tuk-Tuk Siadong, Kabupaten Samosir, Kecamatan Simanindo, Sumatra Utara. Dengan populasi sebanyak 58 orang karyawan. Data yang digunakan adalah data data kualitatif dan kuantitatif , bersumber dari data primer melalui wawancara pada responden dan kuesioner yang sudah valid dan reliabel dengan sebaran data normal, serta data sekunder melalui dokumentasi. Analisis data meliputi analisis mix method (deskriptif kualitatif dan kuantitatif) (Sugiyono, 2013).

\section{HASIL DAN PEMBAHASAN}

\section{Analisis Kualitatif}

Untuk mendapatkan pemaparan secara kualitatif tentang lingkungan kerja dan kinerja karyawan PT Toledo Tuktuk Samosir, disisntesiskan kategori jawaban dari pengelompokan rata-rata jawaban yang diolah dengan jawaban skala likert (Sugiyono, 2013). Hasil pengolahan jawaban kualitatif tersebut dikelompokkan pada tabel berikut:

Tabel 1. Nilai Interval dan Kategori Jawaban Responden

\begin{tabular}{|c|c|c|}
\hline $\begin{array}{c}\text { Nilai } \\
\text { Interval }\end{array}$ & $\begin{array}{c}\text { Lingkungan } \\
\text { Kerja }\end{array}$ & $\begin{array}{c}\text { Kinerja } \\
\text { Karyawan }\end{array}$ \\
\hline $\begin{array}{c}1,00- \\
1,80\end{array}$ & $\begin{array}{c}\text { Sangat Tidak } \\
\text { Baik }\end{array}$ & $\begin{array}{c}\text { Sangat Tidak } \\
\text { Baik }\end{array}$ \\
\hline $\begin{array}{c}1,81- \\
2,60\end{array}$ & Tidak Baik & Tidak Baik \\
\hline $\begin{array}{c}2,61- \\
3,40\end{array}$ & Cukup Baik & Cukup Baik \\
\hline $\begin{array}{c}3,41- \\
4,20\end{array}$ & Baik & Baik \\
\hline $\begin{array}{c}4,21- \\
5,00\end{array}$ & Sangat Baik & Sangat Baik \\
\hline
\end{tabular}

Sumber: hasil pengolahan data (2020)
1) Gambaran Lingkungan Kerja Karyawan PT Toledo Tuktuk Samosir

Lingkungan kerja sudah baik dilihat dari dimensi lingkungan kerja fisik melalui keadaan ruangan yang cukup baik, hal ini disebabkan adanya ruangan yang belum sesuai, seperti ruangan kantor yang sempit sehingga menimbulkan ketidaknyamanan kepada karyawan pada saat bekerja. Kelayakan peralatan yang digunakan dalam bekerja cukup baik, disebabkan masih adanya fasilitas yang kurang baik, seperti kursi dan meja yang sudah lapuk tetap saja digunakan sehingga tidak sepenuhnya meningkatkan kinerja karyawan. Kondisi lingkungan kerja sudah baik, dikarenakan letak hotel PT Toledo Tuktuk Samosir strategis tepat pada pinggir pantai dan memiliki lingkungan yang bersih dan udara yang sejuk.

Selanjutnya pada dimensi lingkungan kerja non fisik dari segi memberikan rasa ketenangan pada saat bekerja sudah baik, disebabkan setiap karyawan di fasilitasi jaminan kesehatan dan tempat tinggal. Kemudian dorongan semangat kerja karyawan masih cukup baik, penyebabnya adalah minimnya komunikasi karyawan terhadap atasan sehingga karyawan kurang termotivasi. Rasa betah karyawan dalam lingkungan kerjanya sudah baik, hal ini disebabkan atasan memberikan fasilitas yang baik pada setiap karyawan seperti menyediakan tempat tinggal yang layak.

Lingkungan kerja secara menyeluruh sudah baik dengan nilai rata-rata 3,45 . Untuk nilai rata-rata maksimum 3,62 kategori baik pada lingkungan kerja non fisik. Sedangkan nilai rata-rata minimum sebesar 3,31 kategori cukup baik pada lingkungan kerja fisik.

2) Gambaran Kinerja Karyawan PT Toledo Tuktuk Samosir

Dari hasil analisis dapat diketahui dimensi dari kuantitas sudah cukup baik, dilihat dari tingkat penyelesaian kerja dimana karyawan terkadang tidak serius dalam melaksanakan pekerjaannya. Tingkat pencapaian target sudah baik karena karyawan mampu menyelesaikan pekerjaanya dengan 
target yang ditentukan oleh perusahaan. Kemudian karyawan mampu mengerjakan lebih dari satu pekerjaan sebagai pekerjaan yang sudah rutin.

Kemudian dimensi kualitas juga sudah cukup baik karena didukung kemampuan karyawan menyelesaikan pekerjaan dengan tidak serius sehingga pekerjaan yang di berikan tidak dapat terselesaikan dengan baik. Penyelesaian pekerjaan dengan terampil sudah baik, karena karyawan memiliki keahlian yang sesuai dengan pekerjaannya. Ketelitian karyawan masih cukup baik, karena masih adanya keluhan dari pengunjung atau tamu hotel akan hasil pekerjaan karyawan.

Kemudian dimensi ketepatan waktu juga cukup baik dikarenakan masih ada karyawan yang bermain handphone pada saat sedang bekerja sehingga waktu yang diberikan untuk suatu pekerjaan tidak terlaksana dengan baik. Tingkat kemampuan karyawan bekerja dengan efisien dikarenakan karyawan dapat menyelesaikan pekerjaan dengan waktu seefisien mungkin. Kemampuan karyawan bekerja dengan efektif sudah baik dikerenakan karyawan mampu menentukan dan memilih cara-cara yang baik yang mana cacra-cara tersebut karyawan mampu mengerjakan suatu pekerjaan dengan waktu yang efektif.

Untuk dimensi kehadiran juga cukup baik dengan tingkat kehadiran karyawan yang cukup baik, penyebabnya masih terdapat karyawan tidak hadir bekerja pada saat masa libur yang di berikan sudah selesai. Kemampuan kerja sama dengan pemimpin juga baik, disebabkan kemampuan karyawan untuk hadir dengan tepat waktu bahkan karyawan juga hadir sebelum jam bekerjaKeinginan karyawan untuk tidak menambah jadwal cuti masih cukup baik, penyebabnya minimnya waktu libur karyawan oleh manajemen.

Dimensi dalam bekerja sama sudah baik karena untuk kondisi tertentu pimpinan dan karyawan saling terbuka satu sama lain mengenai pekerjaan sehingga kerja sama antara karyawan dan pimpinan berjalan dengan baik. Kemampuan karyawan bekerja sama dengan sesam karyawan pada bagian yang sama juga baik, hal ini dikarenakan karyawan dengan senang hati membantu karyawan yang sedang kesusahan. Kemampuan karyawan bekerja sama dengan karyawan lain pada bagian yang berbeda masih cukup baik, hal ini dikarenkan sesama karyawan yang walaupun bagian yang berbeda masih kurangnya kesediaan membantu karyawan yang sedang membutuhkan bantuan.

Kinerja karyawan secara keseluruhan mendapat nilai rata-rata 3,49 kriteria baik. Kemudian nilai rata-rata maksimum 3,75 kategori baik atas kehadiran. Sedangkan nilai rata-rata minimun 3,31 kategori cukup baik pada ketepatan waktu.

\section{Hasil Analisis Kuantitatif}

\section{1) Regresi Linier Sederhana}

Untuk menganailis pengaruh antar variabel maka dengan bantuan aplikasi SPSS diperoleh hasil analisis pada tabel di bawah ini:

Tabel 2. Hasil Regresi Linier Sederhana

\begin{tabular}{|c|c|c|}
\hline \multirow[b]{2}{*}{ Model } & \multicolumn{2}{|c|}{ Unstandardized Coefficients } \\
\hline & B & $\begin{array}{l}\text { Std. } \\
\text { Error }\end{array}$ \\
\hline (Constant) & 29.444 & 3.019 \\
\hline $\begin{array}{c}\text { Lingkungan } \\
\text { Kerja }\end{array}$ & .386 & .046 \\
\hline
\end{tabular}

Sumber: pengolahan data kuesioner (2020)

Hasil analisis pada tabel di atas, diperoleh $\hat{Y}=29,444+0,386 X$, kenaikan satu satuan lingkungan kerja akan memberikan peningkatan yang positif terhadap kinerja karyawan PT Toledo Tuktuk Samosir sebesar 0,386 .

\section{2) Korelasi dan Koefisien Determinasi}

Untuk melihat keeratan hubungan dan kontribusi dari lingkungan kerja dengan kinerja maka akan dianalisis dengan analisis korelasi dan determinasi melalui bantuan aplikasi SPSS dengan hasil yang ditunjukan tabel di bawah: 
Tabel 3. Hasil Korelasi dan Koefisien Determinasi

\begin{tabular}{|l|r|r|l|r|}
\hline Model & $\mathrm{R}$ & $\begin{array}{c}\mathrm{R} \\
\text { Square }\end{array}$ & Adjusted R Square & $\begin{array}{c}\text { Std. Error of the } \\
\text { Estimate }\end{array}$ \\
\hline 1 & $\mathbf{. 7 4 3}^{\mathrm{a}}$ & $\mathbf{. 5 5 2}$ & .544 & 4.89678 \\
\hline
\end{tabular}

a. Predictors: (Constant), Lingkungan Krjaa

b. Dependent Variable: Kinerja

Sumber: pengolahan data kuesioner (2020)

Tabel 3 di atas menunjukkan bahwa hubungan antara lingkungan kerja dengan kinerja kuat dan positif ditunjukkan angka 0,743 (tabel kriteria keeratan hubungan, (Sugiyono, 2013)). Kontribusi dari lingkungan kerja terhadap tinggi rendahnya kinerja karyawan sebesar 55,20\%, dan sisanya merupakan kontribusi variabel lain yang tidak dibahas dalam penelitian ini.

\section{3) Pengujian Hipotesis}

Untuk membuktikan hipotesis yang diajukan maka digunakan uji t, dengan kriteria pengujian penolakan hipotesis jika taraf signifikansi lebih kecil atau sama dengan 0,05 $(\alpha)$. Dengan bantuan aplikasi SPSS diperoleh hasil pengujian berikut ini:

Tabel 4. Perkiraan Nilai thitung

\begin{tabular}{|ll|r|r|}
\hline \multicolumn{2}{|c|}{ Model } & $\mathrm{t}$ & Sig. \\
\hline $1 \quad$ (Constant) & 9.753 & .000 \\
\multicolumn{2}{|c|}{ Lingkungan Kerja } & 8.313 & $\mathbf{. 0 0 0}$ \\
\hline
\end{tabular}

a. Dependent Variable: Kinerja

Sumber: pengolahan data kuesioner (2020)

Dari tabel 4 tersebut, maka hipotesis yang diajukan diterima bahwa lingkungan kerja memiliki pengaruh positif dan signifikan terhadap kinerja karyawan karena memenuhi kriteria signifikansi dibawah 0,05 yakni 0,000. Hasil penelitian ini sejalan dengan penelitian (Tanoyo, Wiwoho and Nugroho, 2015) dan (Dharmawan, 2011) yang menunjukkan perngaruh lingkungan kerja terhadap kinerja karyawan hotel.
Pembahasan

1) Lingkungan Kerja pada PT Toledo Tuktuk Samosir

Dari seluruh jawaban responden mengenai lingkungan kerja pada PT Toledo Tuktuk Samsosir kategori baik, berdasarkan interpretasi jawaban responden dari kuesioner yang dibagikan, namun masih ada indikator yang perlu dioptimalkan kedepannya, yaitu indikator yang di bawah nilai rata-rata. Terlihat dari dimensi lingkungan kerja fisik pada keadaan ruangan yang cukup baik, sehingga untuk mengoptimalkan hal ini ada baikya manajemen hotel manata kembali ruang kerja karyawan sehingga dapat bekerja dengan nyaman. Kelayakan peralatan juga cukup baik, untuk memperbaikinya sebaiknya pemimpin memperhatikan lagi mengenai peralatan yang digunakan oleh mendukung pelaksanaan pekerjaan mereka dan tidak mengecewakan para wisatawan. Kondisi lingkungan kerja dapat dioptimalkan dengan menata lagi lingkungan yang ada di sekitaran perusahaan supaya dapat menarik perhatian para wisatawan. Pada dimensi lingkungan kerja non fisik pada dorongan pimpinan terhadap semangat kerja bawahan masih cukup baik, sehingga diharapkan pimpinan harus lebih aktif lagi memberikan informasi atau arahan kepada karyawan, mereka bekerja dengan semangat dan lebih termotivasi.

2) Kinerja Karyawan pada PT Toledo Tuktuk Samosir

Kinerja karyawan pada PT Toledo Tuktuk Samosir sudah baik, berdasarkan interpretasi jawaban responden dari kuesioner, walaupun masih ada indikator yang perlu ditingkatkan. Dimensi kuantitas pada tingkat penyelesaian kerja yang masih cukup baik, diharapkan pimpinan melakukan pengawasan serta mengarahkan karyawan secara rutin sehingga karyawan memiliki kemampuan menyelesaikan pekerjaan yang diberikan. Dimensi kualitas dalam menyelesaikan pekerjaan dengan baik masih cukup baik, untuk itu sebaiknya pimpinan ikut serta dalam memperhatikan setiap kinerja karyawan sehingga karyawan memperoleh pengawasan yang baik dan dapat 
bekerja dengan serius. Penyelesaian pekerjaan dengan teliti juga masih cukup baik, untuk mengoptimalkan hal ini ada baiknya perusahaan memberikan pelatihan khusus bagi karyawan yang kurang mahir dalam bidangnya supaya tidak mengecewakan para wisatawan. Pada ketepatan waktu dalam menyelesaikan pekerjaan dengan tepat juga cukup baik, sehingga perusahaan lebih mengawasi karyawan dengan baik atau memberikan sanksi kepada karyawan yang terlihat bekerja tidak serius. Pada dimensi kehadiran setiap hari di perusahaan masih cukup baik, untuk meningkatkanya sebaiknya karyawan hadir bekerja dengan tepat waktu dan ketika kembali dari waktu istirahat juga tepat waktu. Keinginan tidak menambah jadwal cuti karyawan masih cukup baik, untuk itu sebaiknya karyawan perlu memperhatikan lagi jadwal cuti yang diambil dan tidak menambah jadwal cuti yang di berikan oleh perusahaan. Pada dimensi kemampuan bekerja sama dalam dimensi tingkat karyawan untuk saling menghargai memperoleh juga cukup baik. Untuk mengoptimalkan hal ini sebaiknya karyawan lebih menjalin komunikasi yang baik untuk pengenalan yang lebih dekat dan harmonis dan mampu berinteraksi dengan baik.

\section{PENUTUP}

\section{Kesimpulan}

Dari hasil analisis dan pembahasan ditemukan bahwa lingkungan kerja sudah baik, namun perlu mengoptimalkan lingkungan kerja non fisik dengan memperhatikan kebutuhan yang dinginkan oleh karyawan misalnya seperti mengawasi peralatan yang tidak memungkin lagi untuk di gunakan oleh karyawan dan menggatikanya dengan layak pakai, contohnya yaitu kursi, meja dan alat-alat kantor lainnya. Kinerja karayawan juga sudah baik, namun masih perlu ditingkatkan dengan memperhatian lagi kinerja karyawan sehingga tidak menurunkan kualitas pendapatan perusahaan dan memberikan dorongan, arahan dan memotivasi karyawan agar lebih giat bekerja. Lingkungan kerja memberikan pengaruh positif dan signifikan pada kinerja karyawa, dan memiliki hubungan yang kuat dan positif.

\section{DAFTAR PUSTAKA}

[1] Al-Omari, K. and Okasheh, H. (2017) 'The Influence Of Work Environment On Job Performance: A case study of Engieering company in Jordan', International Journal of Applied Engineering Research, 12, p. 15544. Available at: https://www.ripublication.com/ijaer17/ijae rv12n24_223.pdf.

[2] Dharmawan, I. M. Y. (2011) Pengaruh Kompensasi dan Lingkungan Kerja Non Fisik Terhadap Disiplin dan Kinerja Karyawan Hotel Nikki Denpasar. Available at: https://d1wqtxts1xzle7.cloudfront.net/466 05104/pengaruh_kompensasi__lingkung an_kerja_non_fisik_terhadap_disiplin.pdf ?1466295326=\&response-contentdisposition=inline $\% 3 \mathrm{~B}+$ filename $\% 3 \mathrm{DPR}$ OGRAM_PASCASARJANA_UNIVERSI TAS_UDAYANA.pdf\&Expires $=1599459$ 773\&Signature $=S$.

[3] Indonesia, P. P. R. (2016) Badan Otorita Pengelola Kawasan Pariwisata Danau Toba. Indonesia.

[4] Lakoy, A. C. (2015) “Pengaruh Komunikasi, Kerjasama Kelompok, dan Kreativitas Terhadap Kinerja Karyawan Pada Hotel Aryaduta Manado", JURNAL EMBA: JURNAL RISET EKONOMI, MANAJEMEN, BISNIS DAN AKUNTANSI, 3(3), p. 981. doi: https://doi.org/10.35794/emba.v3i3.9773.

[5] Mathis, R. L. and Jackson, J. H. (2006) Human Resource Management (Manajemen Sumber Daya Manusia. 10th edn. Jakarta: Salemba Empat.

[6] Sedarmayanti (2001) Manajmen Sumber Daya Manusia. Bandung: Mandar Maju.

[7] Sugiyono (2013) Metode Penelitian Kuantitatif Kualitatif dan R\&D. Bandung: Alfabeta.

[8] Tanoyo, K., Wiwoho, T. Y. and Nugroho, A. (2015) 'Pengaruh Lingkungan Kerja 
Terhadap Kinerja Karyawan Hotel Majapahit Surabaya', Jurnal Hospitality dan Manajemen Jasa, 3(2), p. 410. Available at: http://publication.petra.ac.id/index.php/ma najemen-perhotelan/article/view/3538.

[9] Winarti, A. et al. (2016) 'Pengaruh Lingkungan Kerja dan Kepuasan Kerja Terhadap Kinerja Pada PT Bank Muamalat Indonesia, Tbk. Cabang Pematangsiantar', Maker: Jurnal Manajemen, 2(2). doi: https://doi.org/10.37403/maker.v2i2.41. 


\section{HALAMAN INI SENGAJA DIKOSONGKAN}

